\title{
O SENTIDO DE LUXÚRIA PARA IBN KHALDUN (1332-1406) E A DECADÊNCIA DAS SOCIEDADES URBANAS E DOS CALIFADOS
}

\section{THE MEANING OF LUXURY TO IBN KHALDUN (1332-1406) AND THE DECAY OF URBAN SOCIETIES AND CALIPHATES}

Bárbara Ribeiro Arrudal

Resumo: Entender as concepções de luxúria no Islã se faz importante para compreender até que ponto a religiosidade influencia na visão de política e sociedade do historiador medieval ibn Khaldun (1377), que viveu o período de declínio do Império Islâmico. $O$ trabalho apresentado aqui tem como proposta principal analisar a noção de luxúria nas visões religiosa, política e social do historiador medieval. Em sua metodologia, procura relacioná-las com referências bibliográficas de autores que trabalharam e pesquisaram ibn Khaldun e suas obras, e dessa forma, com a análise da fonte em si, o Muqaddimah (1377) e a sua relação com estas produções contemporâneas. Através de debates sobre seu contexto histórico, social e religioso, discutiremos o conceito de 'asabiyya para Khaldun e o modelo social tribal ao qual faz referência por diversas vezes na Muqaddimah, bem como a contraposição dele para com os centros urbanos e suas críticas aos novos sistemas políticos da sociedade urbana em que vivia.

Palavras-chave: Luxúria; Islã; Medieval; Império Islâmico; Califados.

Abstract: Comprehending the conceptions of lust in Islam is important in order to understand the extent to which religiosity influences the vision of politics and society of the medieval historian ibn Khaldun (1377), who lived through the period of decline of the Islamic Empire. The work presented here has as main proposal to analyze the notion of lust in the

\footnotetext{
${ }^{1}$ Graduanda em História pela Universidade Federal de Campina Grande (UFCG). Email para contato: barbararibeiroarruda@gmail.com. Endereço para o Currículo Lattes: http://lattes.cnpq.br/6650052505713795.
} 
religious, political and social view of the medieval historian and in its methodology seeks to relate them with bibliographic references from authors who worked and researched $i b n$ Khaldun and his works, and thus, the analysis of the source itself, Muqaddimah (1377) and its relationship with these contemporary productions. Through debates about its historical, social and religious context, we will discuss the concept of 'asabiyya for Khaldun and the tribal social model to which it refers several times in the Muqaddimah, as well as their opposition to urban centers and its criticism of the new political systems of the urban society that he lived.

Keywords: Luxury; Islam; Medieval; Islamic Empire; Caliphates.

\section{A luxúria e o Islã, em Ibn Khaldun}

Assim como nas outras religiões do livro, e na maioria das religiões no geral, a luxúria é um conceito negativo devido aos aspectos sociais e espirituais. A luxúria para o Islã seria um indicativo da soberba de uns e da falta de outros, indo de encontro ao que a religião prega sobre a igualdade de todos perante à Allah. Já espiritualmente, a luxúria traria sentimentos que nos afastam de Deus devido ao apego às coisas materiais e a certas práticas consideradas ilícitas pelo Islã.

Entretanto, é preciso compreender que o Islã não proíbe o muçulmano de possuir bens materiais ou conforto (AL-ASSAF, 2019), mas delimita até onde esses bens facilitam a sua vida e a partir de qual ponto apenas envenenam a alma:

Se ele os possui em extensão mínima, deve ter se protegido de pobreza, e se uma pessoa excede isso e estava materialmente confortável, deve ter atingido o que é chamado bem-estar material que denota luxo e conforto do cansaço (AL-ASSAF, 2019, p.3). 
Cadernos de Clio, Curitiba, v. 11, nº. 2, 2020

Ó filhos de Adão, revesti-vos de vosso melhor atavio quando fordes às mesquitas; comei e bebei; porém, não vos excedais, porque Ele não aprecia os perdulários (ALCORÃO, 1975: 7:31).

Teu Senhor prodigaliza e provê, na medida exata, a Sua mercê a quem Lhe apraz, porque está bem inteirado e é Observador dos Seus servos (ALCORÃO, 1975: 17:30).

Para que compreendamos mais a essência do que significa o termo "luxúria" para o Islã, teremos de fazer um comparativo com a nossa noção de raízes cristãs do mesmo termo. Em uma análise do imaginário medieval cristão acerca dos Sete Pecados Capitais, a autora Rejane Barreto Jardim atenta para o fato de que a luxúria, assim como a gula, é considerado um pecado da carne, sendo muitas vezes também considerada como vício, este definido enquanto uma "predisposição permanente para o mal, e por isso, mais grave que o pecado" (JARDIM, 2006: 121). A luxúria também remonta ao Pecado Original, quando Adão desafia as ordens de Deus por orgulho, e posteriormente cai na luxúria. Jardim fala que apesar de ser um pecado originalmente considerado masculino, e, portanto, "predominantemente viril", as mulheres não escapam dele. As mulheres não cometem a luxúria, pois elas são a sua própria personificação.

Portanto, entendemos que por ser um pecado e um vício da carne, na literatura cristã a luxúria está muito mais ligada a questões sexuais, à libido, do que propriamente ao luxo. Para o mundo islâmico, todavia, a luxúria fala de materialidades, como bens, riquezas e conforto. 
Sendo assim, ao contrário da essência cristã, luxúria no islamismo não significa necessariamente harāam (ilegal, em árabe). No Islã, possuir conforto não é negativo, até porque facilita a vida do ser humano para que exerça melhor sua religiosidade. Entretanto, abusar desse luxo, e deixar-se ser corrompido pelos seus valores, não é bem quisto. O luxo, sob medida, deve ser um meio de conforto para facilitar a vida do indivíduo bem como auxiliar no perfeito cumprimento de suas práticas religiosas diárias. Contudo, não deve ser tido como um ideal a ser vivido, uma ambição ou status, pois assim estaríamos nos desviando da real mensagem do Profeta Muhammad e de Allah.

Abd al-Rahman ibn Khaldun (1332-1406) nasceu em 27 de maio, na cidade de Túnis, atual Tunísia. Em 1382, ibn Khaldun decide realizar sua peregrinação a Meca, o Hajj. Quando passa por Alexandria, no Egito, é abordado pelo sultão mameluco Malik Al-Daher Barquq e é enviado para o Cairo. No Cairo, inicia sua carreira política e jurídica. Logo em seguida, em 1384, é nomeado professor de jurisprudência na Universidade Al-Azhar, e também ao cargo de cádi (juiz). Ibn Khaldun perde a mulher e filhos num naufrágio. Desolado, busca refúgio na religião e retoma o Hajj, em 1387.

Ibn Khaldun sempre esteve ao lado dos grandes chefes de Estado, como Malik Al-Daher Barquq e posteriormente seu filho, Al-Nasir Farach. Negociou e virou o historiador oficial do sultão mongol Tarmelão e lutou na marcha em direção a Bujaya, em 1365, no reinado de Tlemcen Abu Hammu II (1339-1989). Muitas vezes foi solicitado pelos líderes por suas habilidades e intelecto, mas, sobretudo, ibn Khaldun tinha consciência de 
que apenas ao lado do poder, numa posição favorável, poderia realizar o seu objetivo de vida - o Kitab al-'Ibar (1377) -, apresentando-nos a sociedade da época sob sua ótica e a sua teoria da História, o que inspiraria inúmeras das ciências humanas do mundo moderno e contemporâneo.

É na porção do Império Islâmico do Magrebe dos séculos XIV e XV, ou seja, na região do Norte da África, abarcando regiões como Marrocos, Argélia, Sahara Ocidental e Tunísia, que se concentra a vida e produção de ibn Khaldun. É também nesse período que identifica um colapso, de cunho moral e político, da organização social de sua sociedade, sendo esses dois pilares da Muqaddimah fundamentais para o declínio do Império Islâmico, na visão do historiador.

Sobre esse período, Albert Hourani fala da perda do poderio do Império Islâmico na região do Magrebe entre os séculos XIV e XV:

Esse segundo período foi um daqueles em que mudaram consideravelmente as fronteiras do mundo muçulmano. Em alguns lugares, as fronteiras contraíram-se sob os ataques dos Estados cristãos da Europa Ocidental. (...) A conquista cristã da Espanha foi completada com a extinção do Reino de Granada em 1492; toda a península era agora governada pelos reinos cristãos de Portugal e Espanha. O poder da Espanha ameaçava o domínio muçulmano no Magreb (...) (HOURANI, 2006: 122-123).

Dessa forma, o Império Islâmico do Magrebe vinha enfrentando situações de conflito e perda de territórios ao redor, principalmente, da porção da Península Ibérica, por conta do avanço dos Estados cristãos. Na 
Muqaddimah, ibn Khaldun critica esse momento do início da decadência do Império, atrelando a esta valores morais e políticos. Ele "identificava a formação do Magreb tardo-medieval entre a decadência política do presente e um glorioso passado vivido em Al-Andaluz" (SENKO, 2009: 75). O intelectual muçulmano, tendo passado parte de sua vida na Península Ibérica, em Al-Andaluz, ao ver os territórios locais - importantes devido ao fluxo comercial e econômico com o Mediterrâneo, além de representarem a parcela do Império Islâmico na Europa - perdidos, buscava "resguardar a essência de Al-Andaluz" (SENKO, 2009: 74).

Sobre a percepção de $i b n$ Khaldun acerca dos motivos do declínio do Império Islâmico, dirá Senko:
A política de sua época era dominada ainda pelos conflitos no Norte de África entre a dinastia dos Hafsidas (1228-1574) e a dinastia dos Marínidas (1196-1465). Além dessas duas grandes dinastias, as quais $i b n$ Khaldun serviu, podemos destacar a importante tribo do norte de África, os Banu Hilal (SENKO, 2009: 75).

Sendo assim, dentro de seu contexto histórico, ibn Khaldun entendeu que o declínio das sociedades organizadas, de caráter urbano, se deu por conta de questões morais, da luxúria. O luxo que acarretou a vida urbana, para ele, enfraqueceu essa sociedade, dando abertura para a investida de tribos como os Banu Hilal. Dirá Hourani:

Historiadores modernos, adotando uma idéia [sic] talvez apresentada primeiro por ibn Khaldun, acostumaram-se a atribuir o declínio da vida organizada no Magreb à chegada de 
algumas tribos árabes, em particular a de Banu Hilal, no século XI. Acha-se que as incursões e depredações delas afetaram profundamente toda a história posterior do Magreb, destruindo os governos fortes que eram os guardiães da vida organizada, mudando o uso da terra da agricultura para a atividade pastoral, e submergindo a população indígena numa maré de nova imigração árabe (HOURANI, 2006: 146).

Apesar de o próprio Hourani seguir dissertando sobre o porquê não acredita que os Banu Hilal tenham tido força suficiente para substituir os berberes por árabes, ou que não fossem contrários à vida organizada do meio urbano, o fato é que ibn Khaldun observa e crê (assim como historiadores influenciados por ele até hoje) que tais investidas tribais tiveram papel importante no declínio da organização social urbana em questão. Todavia, essa força tribal, para o intelectual muçulmano, se dá devido ao aumento da luxúria e perda da 'asabiyya nas sociedades urbanas do Magrebe.

A Muqaddimah, originalmente de 1377, é justamente o prolegômeno do Kitab al-'Ibar. Nela, o autor remete constantemente à luxúria e, de maneira geral, a enxerga mais como algo corruptor e admite ser ela um dos principais motivos da decadência dos califados e do Império Islâmico num geral. Na obra, ibn Khaldun detalha os conflitos entre os diferentes Sultanatos e governos existentes tanto na Península Ibérica quanto no Magrebe Medieval, como se observa no mapa abaixo retratando o Norte da África e a Península Ibérica em XIV: 
Cadernos de Clio, Curitiba, v. 11, nº. 2, 2020

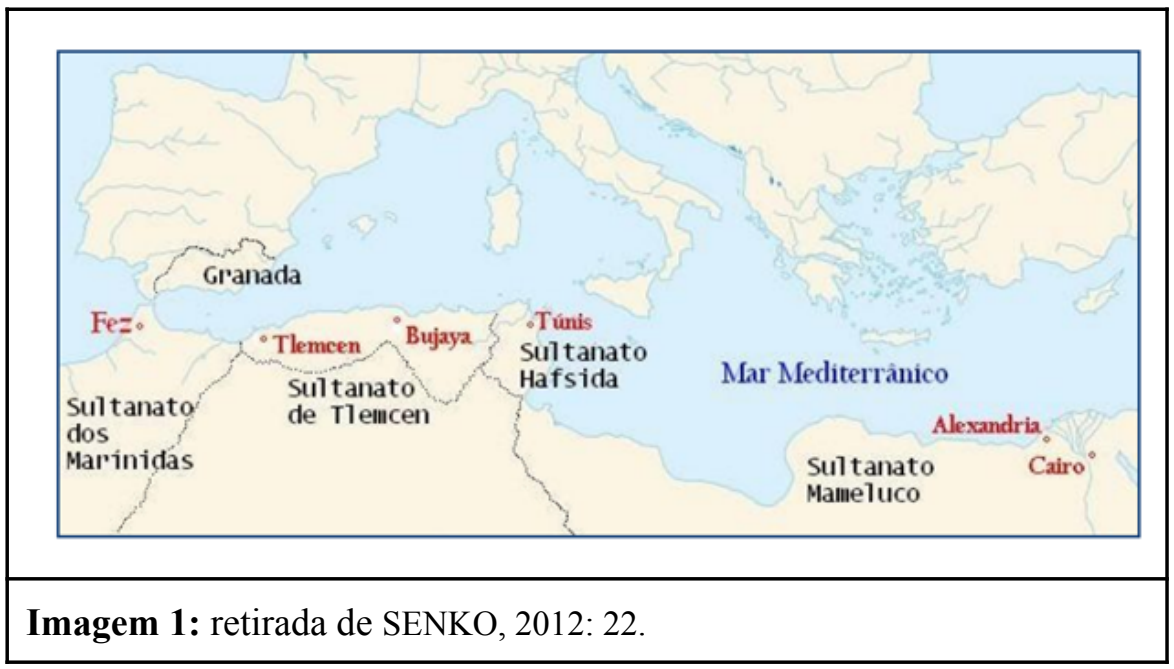

Para o historiador medieval, a origem desses conflitos internos do Império Islâmico se deu a partir da má índole dos governantes. A corrupção, o luxo, a ostentação resultavam na má governabilidade por parte dos chefes de Estado, além da questão religiosa que fundamentava ainda mais seus argumentos. Apesar da convicção política e social, ibn Khaldun também remetia a uma certa punição por Allah devido a essas más condutas:

Além disso, a luxúria corrompe o caráter. [Através do luxo] a alma adquire diversos tipos de costumes maléficos e sofisticados, (...). As pessoas perdem as boas qualidades que eram um sinal e indicação de [sua qualificação para] autoridade real. Eles adotam as qualidades contrárias. Isso aponta para um retrocesso e ruína, de acordo com a maneira que Deus fez [planejou] para Suas criaturas nesta conexão. A dinastia mostra sintomas de dissolução e desintegralização. É 
afetado pelas doenças crônicas da senilidade e finalmente morre (IBN KHALDUN, 1958: 225).

Dessa forma, para o historiador, um bom líder/califa deveria ter comprometimentos morais e religiosos, assim evitando a luxúria. Em sua Muqaddimah, ibn Khaldun se utiliza de califas exemplares, das corrupções de sua sociedade e dos constantes conflitos que se instauram no cenário da África do Norte da época para ilustrar seu ponto de vista sobre como a luxúria interfere nessa instabilidade.

$\mathrm{Na}$ mesma obra, ao comentar sobre as acusações de Al-Rashid ter se embriagado com vinho, o historiador defende o governante, fundamentado na religião. Dirá:

Ele não era um homem de fazer algo proibido e considerado pelos muçulmanos um dos maiores pecados capitais. Nenhuma dessas pessoas [os primeiros Abássidas] tinha nada a ver com prodigalidade efeminada ou luxúria em quesitos de roupas, jóias, ou o tipo de comida que ingeriam. Eles ainda mantinham a atitude forte do deserto e o estado simples do Islã (IBN KHALDUN, 1958: 68).

Desse modo, o autor compreende que, em se tratando do caráter e do comprometimento de Al-Rashid com a religião, ele "manteve a autenticidade dos costumes e não se deixou levar pelo vinho e pela luxúria" (SENKO, 2012: 142), sendo incapaz de ir contra os seus ensinamentos. É 
importante ressaltar que Al-Rashid ${ }^{2}$ foi o exemplo de governante ideal para ibn Khaldun. Portanto, seria impensável um governante digno misturar-se com hábitos que divergiam do Islã.

O Islã em seus ensinamentos permanece o mesmo no que concerne ao conceito de luxúria. Isso porque a base da religião é o Alcorão e este sofreu poucas ou nenhuma mudança do período medieval para o atual. $\mathrm{O}$ conceito religioso de $i b n$ Khaldun, então, segue basicamente a mesma linha dos muçulmanos atuais.

Assim, podemos dizer que a luxúria aparece como uma forma de pecado e desvio do caminho de Deus no islamismo, como por exemplo o pensamento científico no medievo, que não se dissociava da religião e no qual esta estava sempre presente, sendo o mesmo objeto de estudo várias vezes, caso das obras de Avicena, Procópio de Cesarea etc; e na própria obra de ibn Khaldun, nosso objeto.

É interessante ressaltar que os muçulmanos se espelham bastante nos passos dos profetas precedentes, mas principalmente no último, o Profeta Muhammad (570-632), e não seria diferente com ibn Khaldun, que dizia: "Divergir de Seus passos é sinônimo de divergir da forma com que Allah deseja que vivamos" (SANTOS, 2019: 71).

Por isso, ao falarmos da "pobreza da alma" (NURBAKHSH, 2001: 23), um ideal e conceito da vertente islâmica chamada de sufismo, a simplicidade e humildade, atributos do Profeta, são enormemente

${ }^{2}$ Hārūn al-Rashīd, (766/763 - 809), quinto califa da dinastia Abássida (786-809), governou o Islã no apogeu de seu império, em Bagdá, sendo conhecido principalmente por ter sido o fundador da Casa da Sabedoria. 
valorizadas para se atingir a iluminação e poder conhecer-se interiormente. Muhammad era

o modelo dos ideais de pobreza e desapego no sufismo. Para os sufis, ele é o maior exemplo de austeridade por ter vivido na simplicidade, evitando qualquer associação com luxo e riquezas (SANTOS, 2019, p.71).

É justamente por ter sido intocável e incorruptível com os conhecimentos mundanos e com os luxos dessa vida que o coração e o espírito de Muhammad são tidos como os mais puros e dignos de devoção.

\section{A corrupção política e a decadência dos califados na Muqaddimah}

a) As sociedades e a 'asabiyya

Quando nos fala da "atitude do deserto", ibn Khaldun traz à tona sua teoria que constrói em sua narrativa do Muqaddimah. Os povos do deserto, ou seja, as tribos, são a base e o estágio que antecede a urbanização. Nesse momento do século XIV, com o enfraquecimento do Império, as tribos e o nomadismo em geral estão tomando mais força, inclusive por conta do avanço da peste bubônica e do declínio econômico da região (SENKO, 2012: 163). A autora Elaine Senko ao contextualizar sobre o momento histórico e o porquê da pesquisa de $i b n$ Khaldun sobre a 'asabiyya, também acrescenta que:

(...) o ímpeto de construção por parte de ibn Khaldun do conceito de 'asabiyya foi estimulado pelo seu próprio contexto: a diminuição do grande poder muçulmano em 
Al-Andaluz, as pretensões políticas dos sultanatos magrebinos, o medo dos mongóis que avançam sobre o Norte de África e a ascensão dos turcos otomanos na região da Anatólia (SENKO, 2012: 163).

Dessa forma, ibn Khaldun problematiza a vida em civilização, devido ao que já observara em sua vida, e volta-se mais para o estudo do campo e dos povos que ali habitam. Assim sendo, o historiador muçulmano observa que, primeiramente, os grupos humanos buscam sua subsistência, saciando suas necessidades mais básicas ${ }^{3}$. Depois, quando há maior conforto e comodidade com relação a essas necessidades, esses grupos vão se fortalecendo e adquirindo outros tipos de comodidades. Isso é seguido de um aumento no conforto e nas facilidades, as quais levam à formação dos mais desenvolvidos costumes de luxúria (IBN KHALDUN, 1958: 161).

Para ibn Khaldun, o luxo começa a partir do momento em que esses grupos descobrem e criam maneiras de acumular mais riquezas, possuindo maior tempo para descansar e levar um ritmo de vida mais calmo. Alerta, assim, para a ausência de afazeres relacionados à vida frugal para focarem no acúmulo de riquezas e na ostentação do estilo de vida urbano. Ou seja, possuindo o conforto de consciência de que suas necessidades básicas serão atendidas, as pessoas esvaziam suas mentes e a ocupam com a luxúria, segundo ele, corrosivo para a índole humana.

\footnotetext{
3 "Os homens buscam primeiro suas necessidades básicas. Apenas depois de ter obtido o básico que ele irá partir para confortos e luxos. A dureza da vida no deserto precede a suavidade da vida sedentária. Por isso, a urbanização é tida como o objetivo do Beduíno" (IBN KHALDUN, 1377: 164).
} 
Esses povos possuem uma característica chamada de 'asabiyya, que seria o elemento de coesão do grupo (BISSIO apud PINHEIRO FILHO, 2015: 153). Como explica Albert Hourani (2006), as sociedades tribais daquela região possuíam certas noções niveladas de ligação. As primeiras ligações são as mais diretas, por sangue, ou seja, filhos, pais, avôs e avós unidos em prol da manutenção da honra e do bem-estar daquela unidade. A nível maior, temos a ligação por parentesco, "por descendência de um ancestral comum quatro ou cinco gerações atrás" (HOURANI, 2006: 149). E num terceiro nível, temos a ligação por 'asabiyya, por identificação de uma tribo, aldeias e distrito. Esse sentimento da 'asabiyya geraria um pertencimento comum dos indivíduos num grupo, encarando-se como “pertencentes a um todo maior, uma 'fração' ou 'tribo', que veriam como diferente e em oposição a outros grupos semelhantes" (HOURANI, 2006: $150)$.

Dessa forma, esse sentimento coletivo de pertencimento fortalecia o coletivo, ou seja, a tribo, em caso de ameaça e ataque de outros, e também favorecia a ajuda mútua no interior desses grupos. Dirá Hourani que:

A tribo era antes de tudo um nome que existia na mente dos que se diziam ligados uns aos outros. Isso tinha influência potencial sobre suas ações; por exemplo, quando havia uma ameaça comum externa, ou em épocas de migração em larga escala. Podia ter um espírito corporativo ['asabiyya], que levava seus membros a se ajudarem uns aos outros em época de necessidade (HOURANI, 2006: 150). 
A partir dessa 'asabiyya, o grupo/tribo teria ligações mais próximas, inclusive ligações sanguíneas que ligam um indivíduo diretamente ao outro, formando um sentimento mais forte de solidariedade. Para ibn Khaldun, a 'asabiyya era um elemento fundamental para o desenvolvimento dessas tribos. Isso porque ele entende que as tribos que possuem uma 'asabiyya mais forte tendem a governar sobre outros com a 'asabiyya menos forte, a exemplo dos beduínos que, na perspectiva do intelectual, originaram com sua forte 'asabiyya a civilização na qual ele vivia inserido.

Ibn Khaldun constrói essa teoria dizendo que há um processo gradual, porém, cíclico na sua compreensão de sociedade e urbanização (SENKO, 2012: 164). Ele observou que os grandes governantes e as grandes cidades possuem raízes nas tribos, principalmente de beduínos. A 'asabiyya dessas tribos é o que leva à urbanização, a um desenvolvimento desse processo. Todavia, uma vez urbanizados e civilizados, ibn Khaldun marca a decadência desse processo, levando assim ao colapso e atribui à luxúria o motivo deste. Isso porque, para ele, o luxo corrompe esse sentimento de comunidade, levando à corrupção, egoísmo, competitividade interna etc; e, sendo gerados esses valores dentro de uma sociedade, o historiador medieval entende que ela se fragmenta internamente, dando espaço para falhas a partir das quais outras tribos no estágio de forte 'asabiyya irão aproveitar-se como vantagens.

Para o autor da Muqaddimah, a sociedade dividir-se-ia entre nômades e sedentários. Os nômades eram essencialmente as organizações sociais tribais e os sedentários, a população dos centros urbanos. 
Entretanto, Albert Hourani compreende que a divisão não é tão simples assim, já que existiam variações entre ambos:

Seria demasiado simples, portanto, pensar no campo como sendo dividido entre áreas onde camponeses fixados à terra cuidavam de suas colheitas e outros, nômades, se movimentavam com seus animais. Eram possíveis posições intermediárias entre uma vida inteiramente sedentária e uma inteiramente nômade, e essas eram a norma. Era largo o espectro das formas de usar a terra. Em algumas áreas, havia gente assentada, no firme controle da sua terra, o único gado sendo cuidado por empregados; em outras, cultivadores assentados e pastores de carneiros dividiam o uso da terra; em outra ainda, a população era transumante, migrando com seus rebanhos de pastos em baixadas para regiões montanhosas, mas cultivando a terra em certas estações. E ainda em outras, era puramente nômade, mas podia controlar algumas áreas assentadas em oásis e nas margens do deserto onde os camponeses trabalhavam para os nômades (HOURANI, 2006: 142-143).

De fato, $i b n$ Khaldun teria o conhecimento acerca destas variações. Entretanto, quando o intelectual diferencia nômades e sedentários, o faz de acordo com os valores morais. Quando define que a vida nômade agrega mais valores aos indivíduos e fortifica sua 'asabiyya, religiosidade etc; ibn Khaldun compreende que os fatores da terra e a condição de nomadismo interferem sobre as conjunturas sociais, assim como o comodismo que gera o luxo nos povos sedentários dos meios urbanos também. Portanto, para melhor compreensão de sua teoria, evoca os extremos de cada um: do nômade e do sedentário, indo dos exemplos mais tribais e nômades até os 
cargos mais ostentativos e luxuriosos da sociedade urbana, capta a essência de ambos para construção de sua teoria.

Nos mostra Elaine Senko a seguir:

Conseqüentemente [sic], a'asabiyya diminui na vida sedentária luxuosa e dá margem à substituição do poder atual por outro mais animado pela coesão de grupo. Essa visão cíclica, ou melhor, em espiral progressiva, é a fomentadora do tempo histórico multifacetado do viés khalduniano. Trata-se de um processo em mudança permanente, que leva a um período sucessivo de apogeu e posterior desestruturação (SENKO, 2012: 164).

Senko organiza esse processo na seguinte passagem:

Vejamos novamente a ordem de seu pensamento: primeiro o espírito de grupo anima uma dada coletividade, a qual parte para a conquista; depois, quando estabelecida a dinastia e o poder, ela pode se deixar abrandar pelo sedentarismo e a luxuosidade do ambiente citadino, local onde a civilização atingiu seu ápice; tão logo isso ocorrer, perderá progressivamente o seu espírito de grupo, pois o bisneto da família esquecerá suas tradições e a decadência tornaria-se eminente (SENKO, 2012: 170-171).

Para Senko, a 'asabiyya em ibn Khaldun como elemento fundamental de coesão do grupo também é indispensável para a longevidade dessa sociedade. Todavia, o historiador muçulmano observa que com a sedentarização, essa característica vai se perdendo aos poucos, marcando assim o início do fim daquele governo, além de dar lugar a 
outros grupos com a 'asabiyya mais forte dominarem. Ibn Khaldun, dado o seu contexto, compreende que a degradação da 'asabiyya na sua sociedade (ou seja, urbana) dá espaço para a luxúria e a consequente teoria também formulada por ele acerca da decadência dessas sociedades com falta da 'asabiyya forte. Também, o intelectual, ao falar da dominação dos grupos com 'asabiyya forte sobre aqueles com a 'asabiyya fraca, justifica as investidas de povos tribais na sociedade urbana, onde há momentos em que os chefes de Estado precisam recorrer à ajuda e alianças com esses povos, fragilizando e criando uma crise interna dentro do governo (IBN KHALDUN, 1958: 225).

Contudo, o principal elemento que corrompe esse processo continua sendo a luxúria. Ibn Khaldun deixa claro:

Quanto maior o luxo e mais fácil a vida que eles desfrutam, mais próximos estarão da extinção, sem mencionar (a chance perdida de obter) a realeza autoridade. As coisas que acompanham o luxo e a submersão em uma vida tranqüila quebram o vigor do sentimento de grupo, que por si só produz superioridade. Quando o sentimento de grupo é destruído, a tribo não pode mais se defender ou se proteger, muito menos pressionar quaisquer reivindicações. Será engolido por outras nações (IBN KHALDUN, 1958: 187).

O historiador aponta a luxúria como consequência da sedentarização. Os grupos nômades e tribais que possuem a 'asabiyya forte, ou seja, o espírito de união social, são mais propensos à conquista e à gestão própria de uma civilização. Todavia, esses grupos, uma vez sedentários, começam a 
se acostumar com os luxos. Ao analisar o seu próprio meio, ibn Khaldun observa tal fenômeno ao compreender que a perda gradativa da 'asabiyya para a luxúria também culmina no enfraquecimento da força militar, essencial para a defesa do império e da sociedade. Dirá:

Enquanto isso, as pessoas continuam adotando formas cada vez mais novas de luxo e cultura sedentária e de sossego, tranquilidade e suavidade em todas as suas condições, e a afundar cada vez mais neles. Assim, eles se afastam da vida no deserto e da dureza do deserto. Gradualmente, eles perdem cada vez mais (as velhas virtudes). Eles esquecem a qualidade de bravura que era sua proteção e defesa. Eventualmente, eles vêm para depender de alguma outra milícia, se tiverem uma (IBN KHALDUN, 1958: 225).

Isto demonstra que, no espaço de três gerações, chegam os impérios à decrepitude, completam o ciclo de sua evolução, mudando completamente de natureza (IBN KHALDUN apud SENKO, 2012: 157).

O sentimento de união e de coragem que um dia tiveram enquanto tribos é perdido, fazendo com que as forças militares se acovardem e não queiram mais lutar ou proteger sua população. Deixando assim, que outros povos sejam contratados para exercer esse papel, que, futuramente, pela dependência militar, percebem a fraqueza do governante e decidem atacá-los (SENKO, 2012: 164). Fato que, por exemplo, se observa no caso do governo dos Ayúbbida (mamelucos) do Egito que perderam controle para estrangeiros (SENKO, 2012: 166). A partir disso, critica que, ao contrário dos grupos com forte 'asabiyya, que são os povos do deserto, onde a vida é 
árdua e a cooperação coletiva é necessária para sobrevivência de todos, entre os grupos urbanos sucede o sucumbir às facilidades e deleites da luxúria, que leva à fase final da dinastia.

O objetivo do historiador medieval, ao demonstrar isso é, portanto, provar seu ponto de que, dentro de três gerações de governantes, o Império enfrenta seu apogeu e seu declínio. Ibn Khaldun não inclui um antídoto para esse ciclo repetitivo de ascensão e queda dos Impérios, a não ser que se atente (governantes e cidadãos) para a luxúria e sua presença cotidiana.

\section{b) A fase decadente e a luxúria como centro}

O costume de possuir mais do que se necessita faz com que haja mais débito do que se podiam pagar para os governantes, algo que o ibn Khaldun havia dito que se agravaria nas próximas gerações, ocasionando uma situação em que os "governantes impõem sanções às pessoas e privam muitas delas de suas propriedades" (IBN KHALDUN, 1958: 225). A corrupção e o egoísmo são marcas, portanto, que ibn Khaldun não deixa de mencionar em sua obra. Tendo sido durante sua vida muito próximo desse ambiente, deixa claro o que observou e sua intenção ao dizer que:

No cumprimento dos deveres que me competiam, trabalhava com um zelo digno de encômios, empregando todos os meus esforços para justificar a boa opinião do príncipe que me tinha confiado a aplicação dos preceitos divinos. Para não deixar nenhuma presa à maldade dos censores, esforçava-me por aplicar a justiça a todo mundo, sem me deixar influir pela posição ou poderio de quem quer que fosse; protegia o fraco da prepotência do forte; repelia toda a ingerência, toda a 
tentativa, quer de uma parte quer de outra, restrigindo-me a ouvir as provas testemunhais. (IBN KHALDUN apud SENKO, 2012: 26)

Nesse ponto, ibn Khaldun remete ao período em que atuou como cádi (juiz) indicado pelo próprio Barcuque ${ }^{4}$ no Cairo, em 1384. Lá, ele afirma ter vivenciado episódios de corrupção por parte de companheiros da mesma área jurídica. Isso, todavia, teria lhe instigado ainda mais a voltar-se para os estudos e denunciar essas tramas, as quais também levaram a conspirações contra o próprio ibn Khaldun, posteriormente (SENKO, 2012: 35).

Ao deixar a população debilitada, essa fraqueza reflete no próprio governo. Ibn Khaldun descreve que apesar da renda social também ser afetada e tornar-se insuficiente para suas despesas, fazendo com que o governante aumente as taxas tributárias, "a luxúria, enquanto isso, ainda continua aumentando" (IBN KHALDUN, 1958: 225). Compreende, então, que, mesmo diante de toda a situação do declínio imperial, das dificuldades que civis enfrentavam por conta da irresponsabilidade administrativa, o luxo e a ostentação ainda persistiam muito fortes na vida dos governantes e de quem lhes rodeava, fazendo assim com que, cada vez mais, o colapso fosse inevitável, inclusive para o próprio ibn Khaldun, quem já intencionava se afastar do urbano e se voltar para a vida frugal. Se

\footnotetext{
${ }^{4}$ Malique Azair Ceifadim Barcuque (1336-1399) foi sultão e fundador da dinastia mameluca dos burjidas, no Egito.
} 
permanecia nesse meio, era porque recebia ora financiamentos para continuar suas pesquisas, ora bolsas de estudos, ou lecionava.

Tudo isso leva o historiador medieval a falar que quando atingem esse ponto, "dinastias vizinhas, ou grupos e tribos sob o controle da dinastia, começam a atacar, e Deus permite ele sofra a destruição que ele tem destinado a (todas) Suas criaturas" (IBN KHALDUN, 1958: 225). Ou seja, com o enfraquecimento e a crise interna das sociedades islâmicas tanto a perda de territórios na Península Ibérica quanto os conflitos travados entre os próprios califados - e o consequente enfraquecimento da 'asabiyya, os grupos rivais veem nisso uma vantagem e atacam. Aqui, ibn Khaldun nos mostra a fase final da sua tendência cíclica de apogeu e declínio: finalmente, o grande líder perde seu espaço, conquistas e territórios para as outras tribos com maior sentimento de 'asabiyya. A partir daí, recomeça todo o ciclo que intelectual muçulmano explica, indo desde a mais simples forma de comunidade tribal, até um Império e sua decadência.

Tanto na seguinte passagem do Alcorão:

Então, seu profeta lhes disse: Deus vos designou Talut por rei. Disseram: Como poderá ele impor a sua autoridade sobre nós, uma vez que temos mais direito do que ele à autoridade, e já que ele nem sequer foi agraciado com bastantes riquezas? Disse-lhes: É certo que Deus o elegeu sobre vós, concedendo-lhe superioridade física e moral. Deus concede a Sua autoridade a que Lhe apraz, e é Magnificente, Sapientíssimo (ALCORÃO, 1975: 2:247),

quanto no comentário a seguir de ibn Khaldun: 
quando Deus quer que uma nação seja privada da autoridade real, Ele faz com que (seus membros) cometam ações dignas de culpa e pratiquem todo tipo de vícios. Isso levará à completa perda das virtudes políticas entre elas (IBN KHALDUN, 1958: 191).

percebemos que tudo isso é permitido e observado por Allah, que é o único que escolhe quem é ou não é digno de governar uma sociedade.

Para ibn Khaldun, Allah é consciente de tudo o que acontece, sendo através de sua vontade que se dá a designação de punições pelos desvios de seus ensinamentos. Ou seja, uma vez que a sociedade sucumbe à luxúria e ao consequente distanciamento de Deus, o Próprio se encarrega de retirar o governante de lá, por meio, inclusive, do direcionamento forçado a maiores vícios. Ao falar isso, o intelectual justifica não só politicamente seu ponto, como ainda o sustenta nos preceitos divinos. Assim, não apenas os governantes erram, como Deus observa isso e toma os erros como provas de que o governante não é bom o bastante, retirando-o e levando à destruição desse Império para ascensão de outro que Ele julgue adequado o bastante.

Ainda sobre esse distanciamento de Deus, ibn Khaldun falará que:

Os habitantes frugais do deserto e os de áreas habitadas que se acostumaram à fome e abstinência de prazeres são considerados mais religiosos e mais preparados para adoração divina do que pessoas que vivem em luxo e abundância. De fato, pode se observar que existem poucas pessoas religiosas nas cidades e vilas, tanto quanto as pessoas são, na maioria das 
vezes, obstinadas e descuidadas, que estão ligadas ao uso de muita carne, temperos e trigo fino. A existência de homens piedosos e os ascetas é, portanto, restrita ao deserto, cujos habitantes comem frugalmente. Da mesma forma, pode-se observar a condição dos habitantes de uma única cidade difere de acordo com a distribuição diferente de luxo e abundância (IBN KHALDUN, 1958: 130).

E, no Alcorão: "Porque os perdulários são irmãos dos demônios, e o demônio foi ingrato para com o seu Senhor" (ALCORÃO, 17:27).

Entende-se, a partir do Muqaddimah, que os habitantes de cenários mais rigorosos como os do deserto são mais religiosos e ascéticos do que a população das cidades. Segundo o que é compreensível, ibn Khaldun mostra aqui como a luxúria (a comida também entra como uma forma de luxo nessas passagens do Muqaddimah) e seus diferentes níveis afetam na vida religiosa. O historiador muçulmano, como produto de seu tempo, ao presenciar tramas e redes de esquemas e corrupções nos califados em que esteve e nos cargos públicos em que atuou, observa que é muito menos provável que essa sociedade urbana esteja próxima de Allah, do que os grupos tribais, os quais se aproximam muito mais do estilo de vida do Profeta, mas também, do afastamento de aspectos mundanos. Isso é importante porque é também nesse ponto religioso em que se baseiam os motivos sociais da sua teoria sobre o momento de decadência do Império Islâmico.

Ainda, é possível perceber aspectos da pobreza e humildade como muito importantes para o exercício da vida religiosa no Islã, tendo como 
maior exemplo o próprio Profeta Muhammad. Nos ahādīth, encontramos passagens como esta:

Abu Huraira contou que escutou o Mensageiro de Deus dizer: "Abstende-vos do que vos pró́bo, e quando vos ordeno algo, cumpri na medida que podeis. Não me questioneis acerca das questões que vos mencionei. $\mathrm{O}$ que levou os povos que vos precederam para a perdição foi a sua insistência em fazerem perguntas sobre as questões desnecessárias, além de manterem divergências com seus profetas" (HADITH: 9).

Para os muçulmanos, seguir os passos do Profeta é bastante importante, e é por isso que os ahādīth foram reunidos numa compilação. É a partir deles que os muçulmanos têm uma maior noção de como o Profeta viveu sua vida e tentam espelhar-se ao máximo nestes ensinamentos. Por essa noção, ibn Khaldun compreende que é mais provável que se encontrem pessoas mais devotas e religiosas no deserto, na vida árdua, do que nos centros urbanos, repleto de luxo já que essa é uma vida bastante divergente da que levou Muhammad.

\section{Conclusão}

A religiosidade influencia o pensamento e a percepção da realidade de $i b n$ Khaldun, mesmo que sua análise política esteja sólida sem a própria. Entretanto, para chegar no ponto comum entre pecado e corrupção, a base religiosa que recebeu como muçulmano medieval foi bastante importante.

Enquanto um contemporâneo do século XIV, o historiador vive o momento da decadência cada vez maior do Império Islâmico (SENKO, 
2011: 4). O sentimento nostálgico de pertencer a um Império que antes fora tão admirado e temido se encontra nas suas obras, assim como na de outros autores que se assemelham a ele ${ }^{5}$.

Desse modo, a tentativa de justificar a queda do Império baseado na religião como vontade de Deus e, ainda, a retrospectiva nostálgica e saudosa do passado daquele povo árabe do tempo das tribos e do deserto, nos leva a concluir a constante inquietude do historiador diante desse declínio:

no campo os homens seriam mais corajosos e se animam por desejar conquistar algo para suas famílias, enquanto que nas cidades a conquista já foi realizada e a luxúria, em contraste com a miséria aliada à Peste Negra e o descaso, são as máximas (IBN KHALDUN apud SENKO, 2011: 4).

O homem do campo/rural, para $i b n$ Khaldun, seria aquele afastado da vida urbana, o qual também chama de "povo do deserto". Na visão do intelectual muçulmano, esses povos tinham todo um futuro pela frente rumo à civilização. No processo evolutivo e cíclico que teoriza, o historiador denota qualidade de asceticismo, bravura, e claro, de uma forte 'asabiyya nas organizações mais tribais. Já frente ao meio urbanizado, onde era de se esperar encontrar pessoas cultas, eruditas, ibn Khaldun demonstra

5 "Essa realidade do século XIV - instável políticamente, mas agraciada com um passado cultural tão rico e esplendido - também oferecia meios para obras literárias como As Mil e uma noites serem reunidas e resgatadas pelo governo mameluco, numa clara alusão nostálgica frente à um tempo que presenciava o declínio do poder islâmico" (SENKO, 2010: 13). 
tremenda decepção. Os centros urbanos agora eram concentração da corrupção, luxúria de um lado e pobreza do outro, além de um fraquíssimo sentimento de solidariedade e de desenvolvimento do Império.

Estar imerso nesse período em um dos Impérios mais poderosos da História, porém vendo-o definhar, de fato deve tê-lo levado a considerar que um possível Yaum Al-Qiyamah (dia do julgamento no Islã) estava próximo. Quando ibn Khaldun fala da construção de prédios cada vez mais altos, imediatamente lembramos da crença muçulmana que o fato de prédios cada vez mais altos serem construídos é um dos sinais da aproximação desse dia, devido à história da Torre de Babel, que

Segundo o Antigo Testamento (Gênesis 11:1-9), torre construída na Babilônia pelos descendentes de Noé, com a intenção de eternizar seus nomes. A decisão era fazê-la tão alta que alcançasse o céu. Esta soberba provocou a ira de Deus que, para castigá-los, confundiu-lhes as línguas e os espalhou por toda a Terra. (SOUSA, s./d.: não p.)

Portanto, é perceptível o receio do Al-Din pelo historiador do medievo islâmico, e como ele se justifica e se assemelha à situação decadente do Império Islâmico.

A luxúria aparece, então, para ibn Khaldun, como a maior causadora disso, dado que o conceito de luxúria abarca e generaliza muitas das ações divergentes religiosamente e corruptíveis moralmente para ele. Ibn Khaldun acha na luxúria a fundamentação e justificativa perfeitas para explicar a situação da sociedade em que vivia. Desde o distanciamento de Allah, 
passando pela sua punição até a corrupção dos governantes da época, a luxúria se fez um conceito de frequente uso por ibn Khaldun na Muqaddimah.

\section{Referências}

AL-ASSAF, Tamam O. Abdullah. Luxury in Islam, Between Prohibition and Permissibility. International Journal of Liberal Arts and Social Science, Tine and Wear, v. 7, n. 10, nov. 2019.

ALCORÃO Sagrado. Trad. Samir El Hayek. São Paulo: Tangará, 1975.

BISSIO, Beatriz. Islã medieval: o espaço teorizado e o espaço vivido. In: SIMPÓSIO NACIONAL DE HISTÓRIA, 24., 2007, São Leopoldo. Anais do XXIV Simpósio Nacional de História, São Leopoldo: Unisinos, 2007. p. $1-8$.

CONCEITO DE. Conceito de luxúria. Dísponível em: $<$ https://conceito.de/luxuria $>$. Acesso em: 03 mar. 2021.

HOURANI, Albert. Uma História dos Povos Árabes. São Paulo: Companhia das Letras, 2006.

JARDIM, Rejane Barreto. A Luxúria como Herança de Adão. Revista OPSIS, Catalão, v. 6, n. 1, p. 120-128, mar. 2006.

KHALDUN, Abd Ar Rahman bin Muhammed ibn. The Muqaddimah. Trad. Franz ROSENTHAL 1. ed. Nova Iorque: Pantheon, 1958. Original em árabe.

NURBAKHSH, Javad. La pobreza espiritual en el Sufismo. Santa Cruz de La Sierra: Editorial NUR, 2001. 
OS QUARENTA HADITH (DITOS). Disponível em: $<$ https://d1.islamhouse.com/data/pt/ih_books/single/pt_forty_Hadith.pdf $>$. Acesso em: 03 mar. 2021.

PINHEIRO FILHO, Carlos Douglas Martins. O poder no islã clássico e na filosofia política de ibn Khaldun: um estudo dos conceitos de Umma e Assabiya. Enfoques, Rio de Janeiro, v. 14, n. 1, p. 147-158, 2015.

SANTOS, Delano de Jesus Silva. A Espiritualidade de Maomé no Sufismo. Revista Caminhos, Goiânia, v. 17, n. 1, p. 65-79, jan./jul. 2019.

SAYURI, Juliana. Como é o al-Din, o fim do mundo islâmico? Superinteressante. São Paulo, 14 fev. 2020. Disponível em: $<$ https://super.abril.com.br/mundo-estranho/como-e-o-al-din-o-fim-do-mun do-islamico/>. Acesso em: 03 mar. 2021.

SENKO, Elaine Cristina. A Concepção de Cidade para o Historiador Medieval Ibn Khaldun (1332-1406) no Século XIV. In: Jornada de Estudos Antigos e Medievais, 10., 2011, Maringá. Anais da Jornada de Estudos Antigos e Medievais. Maringá: UEM, 2011. p. 1-9.

- O Passado E O Futuro Assemelham-Se Como Duas Gotas D’água: Uma Reflexão Sobre A Metodologia Da História De Ibn Khaldun (1332-1406). 2012. 208 f. Dissertação (Mestrado em História) - Setor de Ciências Humanas, Letras e Artes, Universidade Federal do Paraná, Curitiba (PR), 2012.

- O Resgate Do Pensamento Historiográfico Clássico Na Idade Média Islâmica: Considerações Sobre A Escrita Da História Por Ibn Khaldun (1332-1406). Revista Alétheia de Estudos sobre Antigüidade e Medievo, Jaguarão, v. 2, n. 2, p. 1-15, ago./dez. 2010.

. Um panorama sobre a Historiografia Islâmica na Idade Média: um diálogo necessário. Revista Vernáculo, Curitiba, n. 39, p. 6-19, jan./jun. 2017. 
Cadernos de Clio, Curitiba, v. 11, nº. 2, 2020

SOUSA, Rainer Gonçalves. História da Torre de Babel. História do Mundo. Disponível em: $<$ https://www.historiadomundo.com.br/babilonia/torre-babel.htm $>$. Acesso em: 03 mar. 2021.

YAHYA, Harun. Portents and Features of the Mahdi's Coming. Jacksonville: Global Publishing, 2010.

Recebido em: 04/03/2021 Aceito em: 16/04/2021 